\title{
Protein hydrolysates from Alphitobius diaperinus and Hermetia illucens larvae treated with commercial proteases
}

\author{
G. Leni ${ }^{1}$, L. Soetemans ${ }^{1,2}$, J. Jacobs ${ }^{3}$, S. Depraetere ${ }^{3}$, N. Gianotten ${ }^{4}$, L. Bastiaens ${ }^{2}$, A. Caligiani ${ }^{1}$ and S. Sforza $^{{ }^{*}}$ \\ ${ }^{1}$ Department of Food and Drug, University of Parma, Parco Area delle Scienze, 27/A, 43124 Parma, Italy; ${ }^{2}$ VITO, Flemish \\ Insititute for Technolgical Research, Boeretang 200, 2400 Mol, Belgium; ${ }^{3}$ Circular Organics, Slachthuisstraat 120/6, 2300 \\ Turnhout, Belgium; ${ }^{4}$ Protifarm, Harderwijkerweg 141B, 3852 AB Ermelo, the Netherlands; stefano.sforza@unipr.it
}

Received: 5 August 2019 / Accepted: 2 March 2020

(c) 2020 Wageningen Academic Publishers

OPEN ACCESS CC)

\begin{abstract}
Insect proteins have been proposed as a promising alternative for feed and food formulations. In the present work protease-assisted extraction was studied as a way to separate and extract proteins from two different insect species: Alphitobius diaperinus (AD) and Hermetia illucens (HI). The proteolytic activity of seven enzymes (papain, pancreatin, dispase I, pepsin, protease from Bacillus licheniformis, bromelain and trypsin) was evaluated determining the protein extraction yield, the degree of hydrolysis (DH) and the released free amino acids (FAA). Both insects represent an interesting source of proteins, not only for their amount (more than $40 \%$ on dry matter) but also for the nutritional value, with essential amino acid profile exceeding the requirements proposed for human nutrition. Enzyme-assisted protein extraction, performed at laboratory scale, gave for $\mathrm{HI}$ an average yield of extraction of $71 \pm 8 \%$ and for $\mathrm{AD}$ $67 \pm 6 \%$. Hydrolysates produced from HI gave a DH\% ranging between 3 to $18 \%$, whereas hydrolysates produced from $\mathrm{AD}$ yielded a $\mathrm{DH} \%$ between 7 to $23 \%$. The protein hydrolysates were composed by peptides and FAA (which accounted for more than $30 \%$ of the extracted protein fraction), which were released according to their abundance in initial protein. A moderate correlation between the $\mathrm{DH} \%$ and the total amount of FAA was found, except for AD hydrolysed with trypsin and $\mathrm{HI}$ with papain. Based on these results, the production of hydrolysates was preliminary scaled up in a proof-of-concept experiment, focusing on the most promising insect-enzyme combination. The final product resulted to be rich in protein (60\% on dry matter). This work support enzymatic hydrolysis as an effective method to extract and isolate proteins from insects, with minimal sample preparation, tailoring their composition, preserving the nutritional quality, decreasing the risk of allergic reactions and making them more accessible for their future use as feed/food supplements.
\end{abstract}

Keywords: enzymatic assisted extraction, insect, novel protein source, degree of hydrolysis, free amino acids

\section{Introduction}

A generalised consensus on the need to find alternative protein sources for feed and food applications is currently shared by feed and food producers, as well as researchers in the field. Increasing world population, as well as rising meat consumption per capita in developing nations, boost the necessity to find new protein sources. Novel protein sources, derived from diverse food by-products and other residual biomasses (e.g. seeds, bran, peels from plant origin) or from newly used biomasses (algae) are being recently proposed in European Union (EU) as an alternative to more commonly used proteins (FAO, 2009). Unfortunately, the diversity in protein composition and matrices represents a technological problem for a cost-competitive and a low impact processing (Russ and Meyer-Pittroff, 2004; Tuck et al., 2012). Insects may constitute a possible biotechnological solution to the above problems, since some of them naturally develop on organic wastes and various biomass types. Insects incorporate the nutrients into their bodies, both reducing the amount of waste material and generating a more homogeneous and valuable biomass (Li et al., 2011; Rumpold and Schlüter, 2013; Smetana et al., 2016). This 'indirect' biorefinery through insects represents a way to 
convert a variety of feedstocks into marketable protein end-product (Van Huis, 2013).

Insects indeed represent an optimal source of proteins: protein amount is from 39 to $64 \%$, on dry matter basis, with a high content of essential amino acids, making them nutritionally relevant for human and animal consumption (Chen et al., 2010; Sánchez-Muros et al., 2016). From the legal point of view, Regulation (EC) No 999/2001 (EC, 2001) authorises the use of insect protein meals for feeding pet and fur animals, whereas forbids them for ruminants and monogastric animals. The Regulation (EC) No 2017/893 (EC, 2017) authorised the use of insect protein meals originating from seven species (including black soldier fly, Hermetia illucens, and lesser mealworm, Alphitobius diaperinus) as feed for aquaculture animals. The European Commission is currently exploring the possibility to extend their use also for feeding poultry. Regarding the food sector, from the $1^{\text {st }}$ January of 2018 insects are considered novel foods, and as such, need to have EFSA safety evaluation and EU Commission approval before being placed on the market (EC, 2015).

Insect proteins meals can be obtained by different processes (e.g. chemicals, mechanical, enzymatic). Often, the protein fractionation process results in a trade-off between yield and purity (Sosa and Fogliano, 2017), thus the preparation of protein meals of acceptable purity in a cost competitive way is a challenging task. In literature, many protocols of protein extractions from insects have been proposed, often combined with a delipidating pre-step. In a previous work from our group, more than $90 \%$ of the total proteins in black soldier fly was extracted from delipidated prepupae by applying the Osborne fractionation, normally used for cereals (Caligiani et al., 2018). Zhao et al. (2016) obtained $75 \%$ protein yield with an alkali extraction on delipidated yellow mealworm larvae. In other works, the protein extraction process was applied directly on insect flour, without any step of defatting. Purschke et al. (2018a) combined the action of $\mathrm{pH}$ with a centrifugal fractionation, recovering 58\% proteins from Tenebrio molitor. A complete protein recovery was obtained by Yi et al. (2017) on $T$. molitor using high extraction $\mathrm{pH}$ in combination with $\mathrm{NaCl}$. Soetemans et al. (2019) used different organic acids as adjuvants to improve lipid and protein extraction from black soldier fly.

Enzymatic hydrolysis is widely used in the food/feed sector in order to extract proteins from vegetables and meat by-products and is also exploited in order to obtain ingredients with bio- and techno-functional properties (Del Mar Contreras et al., 2019; Lynch et al., 2018). Enzymes are able to increase the amount of proteins extracted in forms of peptides by enhancing solubility, through a decrease in the molecular mass, and an increase in both repulsive interactions between peptides and hydrogen bond interactions with water molecules (Zhao et al., 2012). The use of exogenous enzymes for a food/feed industrial process presents many advantages. First, the use of proteases could make the protein extraction process more controllable and reproducible, cheap and environmentally friendly (Ahmadifard et al., 2016). The obtained hydrolysates have a high nutritional value, since hydrolysis makes the protein fraction more digestible, and essential amino acids are preserved by the mild conditions used during enzymatic hydrolysis. Moreover, the protein fractions obtained might be hypoallergenic, since allergenic proteins are also degraded to peptides. Finally, the peptides released during the hydrolysis might present bio-functional activities (Meinlschmidt et al., 2015).

Among other applications, enzymatic extraction is nowadays employed in the shrimp processing industry for separating proteins from chitin wastes (Mizani et al., 2005). Given the close genetic relation between crustaceans and insects, a similar process could probably be easily expanded also in the insect biorefinery. The use of proteolytic enzymes on insect biomass has been previously studied mostly in the perspective to obtain a techno functional and/or a biofunctional final protein product (Nongonierma and FitzGerald, 2017). Purschke et al. (2018b) compared the ability of different enzymes, used at a different concentration and for a different hydrolysis time, to solubilise proteins from a commercial locust protein flour. With the addition of enzyme, they were able to significantly increase the amount of solubilised protein from about 5 to $30 \%$. Hall et al. (2017) evaluated the increasing of protein extraction during the enzymatic hydrolysis of crickets. They demonstrated that with the use of alcalase the percentage of extractable proteins increased from $3 \%$ up to about 15\%, depending on the enzyme concentration and hydrolysis time. In a recent paper from our group, a thermal treatment as killing method was combined with an enzymatic hydrolysis in order to extract $97 \%$ of total proteins from H. illucens in form of peptides (Leni et al., 2019). Despite the previous examples, the ability of different enzymes acting on the same substrate to enhance protein extraction has never been studied and compared in detail, and no data are reported on the detailed molecular composition of the obtained hydrolysates.

In the present work, the use of proteases as biotechnological adjuvant for protein extraction from raw untreated ground insects was systematically explored, as a way to boost the efficiency of the process and to obtain protein hydrolysates in an easy and efficient way. The ability of seven different commercial proteases to produce protein hydrolysates at a laboratory scale from larvae of $A$. diaperinus and $H$. illucens was deeply studied and compared, also focusing on the fine molecular composition and nutritional value of the obtained products. Furthermore, as a proof of concept, 
the process was scaled up, focusing on the most promising insect-enzyme combination.

\section{Material and methods}

\section{Material}

Kjeldahl defoamers and catalyst were purchased from Merck (Darmstadt, Germany). AccQ-Fluor reagent kit and AccQ-TagTM were obtained from Waters (Milford, MA, USA). DL-norleucine, amino acid standard mixture, glutamine, asparagine, tryptophan, o-phthaldialdehyde, $\mathrm{N}$-acetyl-1-cysteine, DL-isoleucine and all of the enzymes tested were purchased from Sigma-Aldrich (St. Louis, MO, USA). All the other solvents, salts, acids and bases (analytical grade) were purchased from Sigma-Aldrich or Carlo Erba (Milan, Italy).

\section{Insect samples}

Black soldier fly (H. illucens, HI) larvae were provided by Circular Organics (Turnhout, Belgium), whereas lesser mealworm $(A$. diaperinus, $\mathrm{AD})$ larvae by Protifarm (Ermelo, the Netherlands). HI and AD larvae were reared in a temperature and humidity-controlled room, with standard temperature ranging between 28 and $32{ }^{\circ} \mathrm{C}$ and humidity above $60 \%$. Larvae were fed daily ad libitum with the standard rearing feed. At the end of the rearing cycle (15 days for $\mathrm{HI}$ and 28 days for $\mathrm{AD}$ ) the larvae were separated from the frass and transported alive in trays. Larvae were killed by packing them in vacuum sealed containers and freezing at $-30{ }^{\circ} \mathrm{C}$. After one week, dead larvae were freezedried and stored at $-20^{\circ} \mathrm{C}$ until the analysis. Before each analysis, whole larvae were ground for $2 \mathrm{~min}$ with IKA A10 laboratory grinder (IKA Werke GmbH \& Co. KG, Staufen, Germany). Three different trials were performed for each insect species.

\section{Proximate composition}

Moisture, nitrogen, lipid and ash were determined using standard procedures (AOAC, 2002). Crude lipid content was determined by using an automatized Soxhlet extractor (VELP SCIENTIFICA, Usmate, Italy) with diethyl ether as solvent. Total nitrogen was determined by a Kjeldahl system (VELP SCIENTIFICA, Usmate, Italy). The nitrogen coefficient conversion for $\mathrm{HI}$ and $\mathrm{AD}$ proteins was obtained by total amino acid composition, assuming an equimolar amount of Asn/Asp and Gln/Glu (respectively, 5.50 for HI, and 5.67 for $\mathrm{AD}$ ). The determination of chitin is described below.

\section{Total amino acids analysis of insects}

$25 \mathrm{mg}$ of dilapidated ground insects and $3 \mathrm{ml}$ hydrolysis reagent (phenol $(1 \mathrm{~g} / \mathrm{l})-\mathrm{HCl}(6 \mathrm{M}))$ were mixed and heated at $110{ }^{\circ} \mathrm{C}$ for $23 \mathrm{~h}$. For cysteine measurements, an additional sample was oxidised prior to hydrolysis with performic acid/ phenol. After heat treatment, the samples were centrifuged for $5 \mathrm{~min}$ at $3,000 \times g$ to remove solid particles. Amino acids were analysed by high-performance anion exchange chromatography with pulsed amperometric detection in Chromeleon software. The conditions of analysis were the following: column Dionex AminoPac PA-10 (2×250 nm) and Dionex AminoPac PA-10 Guard $(2 \times 50 \mathrm{~mm})$ at $30{ }^{\circ} \mathrm{C}$; mobile phases (A) milliQ water, (B) $250 \mathrm{mM} \mathrm{NaOH}$, (C) 1 $\mathrm{M} \mathrm{NaOAc}$ (D) $0.1 \mathrm{M}$ Acetic acid; gradient 0-2 min: eluent A (76\%) and B (24\%), 2-11 min: eluent A (64\%) and B (36\%), 11-47 min eluent A (40\%), B (20\%), C (40\%), 47.1-49.1 min: eluent D (100\%), 49.2-51.2 min: eluent A (20\%) and B (80\%), 51.3-76 min: eluent A (76\%) and B (24\%) at $0.250 \mathrm{ml} / \mathrm{min}$. Volume of injection was $10 \mu \mathrm{l}$.

Tryptophan (Trp) was determined following the method proposed by Delgado-Andrade et al. (2006) with some modifications. $0.2 \mathrm{~g}$ of dried insect sample were weighed into a $7 \mathrm{ml}$ Pyrex glass tube and dissolved in $3 \mathrm{ml}$ of $4 \mathrm{M}$ $\mathrm{NaOH} .150 \mu \mathrm{l}$ of 5 -methyl-tryptophan $(0.16 \mathrm{mg} / \mathrm{ml})$, used as internal standard, were added and mixed. Hydrolysis was then carried out at $110{ }^{\circ} \mathrm{C}$ for $18 \mathrm{~h}$. After letting the tubes to cool at room temperature, the solution was carefully acidified to $\mathrm{pH}=6.5$ with $\mathrm{HCl}$, then diluted to 25 $\mathrm{ml}$ with sodium borate buffer $(0.1 \mathrm{M}, \mathrm{pH}=9.0)$. Sample was centrifuged at 4,000 rpm for $5 \mathrm{~min}$ and supernatant filtered through $0.45 \mu \mathrm{m}$ nylon filter membrane into UPLC vials. Trp content was calculated by dividing the area of the peak by the area of the internal standard and multiplying this value by the weight of the internal standard and the response factor of tryptophan. UPLC/ESI-MS analysis was performed by using an ACQUITY UPLC separation system with an Acquity BEH C18 column (Waters Corporation, Milford, MA, USA). The mobile phase was composed by $\mathrm{H}_{2} \mathrm{O}+0.2 \% \mathrm{CH}_{3} \mathrm{CN}+0.1 \% \mathrm{HCOOH}$ (eluent $\mathrm{A}$ ) and $\mathrm{CH}_{3} \mathrm{CN}+0.1 \% \mathrm{HCOOH}$ (eluent B). Gradient elution was performed according to the following steps: isocratic 100\% A for 1.8 mins, from $100 \%$ A to $50 \%$ A by linear gradient in 11.4 mins and 0.8 mins at $50 \%$ A plus washing step at $0 \% \mathrm{~A}(100 \% \mathrm{~B})$ and reconditioning. Flow rate was set at $0.25 \mathrm{ml} / \mathrm{min}$, injection volume $4 \mu \mathrm{l}$, column temperature $35{ }^{\circ} \mathrm{C}$ and sample temperature $23{ }^{\circ} \mathrm{C}$. Detection was performed by using Waters SQ mass spectrometer with the following conditions: ESI source in positive ionisation mode, capillary voltage $3.2 \mathrm{kV}$, cone voltage $30 \mathrm{~V}$, source temperature $150{ }^{\circ} \mathrm{C}$, desolvation temperature $300{ }^{\circ} \mathrm{C}$, cone gas flow $\left(\mathrm{N}_{2}\right): 100 \mathrm{l} / \mathrm{h}$, desolvation gas flow $\left(\mathrm{N}_{2}\right): 650 \mathrm{l} / \mathrm{h}$, SIR acquisition mode at 188,0 and 205,0 for Trp; 202,1 and 219,1 for 5-methyl-tryptophan $\mathrm{m} / \mathrm{z}$, scan duration $1 \mathrm{~s}$. 


\section{Determination of chitin}

Quantification of the chitin content was performed as described by D'Hondt et al. (2020). Briefly, chitin was hydrolysed to glucosamine and acetate that were subsequently quantified by LC-MS and HPLC-RID, respectively. The sample was hydrolysed with $6 \mathrm{~N} \mathrm{HCl}$ for $6 \mathrm{~h}$ at $110^{\circ} \mathrm{C}$. Glucosamine was determined by UPLC-MS/ MS analysis (Waters UPLC BEH HILIC $2.1 \times 100 \mathrm{~mm}, 1.7$ $\mu \mathrm{m}$ column at $40^{\circ} \mathrm{C}$, isothermal gradient elution using water with (A) $20 \mathrm{mM}$ ammonium formiate and $0.1 \%$ formic acid $(\mathrm{pH}=3)$ and acetonitrile (B) with $0.1 \%$ formic acid with gradient settings: $5-25 \% \mathrm{~A}$ (0-3 min), $25 \% \mathrm{~A}$ (3-4 min), 25$5 \% \mathrm{~A}(4-4.1 \mathrm{~min}), 5 \% \mathrm{~A}(4.1-7 \mathrm{~min})$ at $0.4 \mathrm{ml} / \mathrm{min}$ at $40^{\circ} \mathrm{C}$ ). Peak detection and quantification were done using a triple quadrupole MS operated in multiple reaction monitoring mode.

\section{Enzymatic assisted extraction}

The enzymes employed were: protease from Bacillus licheniformis (PBL) ( $\geq 2.4 \mathrm{U} / \mathrm{g}$; EC number 3.4.21.62), dispase I ( $\geq 10$ unit/mg; EC number 255-914-4), pepsin from porcine gastric mucosa ( $\geq 250$ units/mg; EC number 3.4.23.1), pancreatin from porcine pancreas (8xUSP; EC number 232-468-9), trypsin from porcine pancreas (1.0002.000 BAEE units/mg; EC number 3.4.21.4), bromelain from pineapples (2 mAnson U/mg; EC number 232-5724) and papain from papaya latex (1.5-10 units/mg; EC number 3.4.22.2). These enzymes were chosen among common commercial enzymes for being representative of diverse sources, being of vegetal (papain), bacterial (PBL, dispase) or animal (pepsin, trypsin, pancreatin) origin. The hydrolysis reactions were carried out on ground insects at a laboratory scale, in triplicate, in the optimal condition for each enzyme, following the indications provided by the manufacturer, which are reported in Table 1.

As general procedure for the hydrolysis, $5 \mathrm{~g}$ of ground insects were mixed, in a $50 \mathrm{ml}$ falcon tube, with $45 \mathrm{ml}$ of the specific solution above reported, and $0.05 \mathrm{~g}$ of enzymes were added at room temperature. The falcon tube was then placed in a heating bath at the correct temperature (Table 1) and mixed with a magnetic stirrer. The hydrolysis reaction was carried out for $18 \mathrm{~h}$ in order to reach the plateau phase. The enzymes were inactivated by heating at $90{ }^{\circ} \mathrm{C}$ for 5 $\mathrm{min}$. The hydrolysates were then centrifuged (5810/ 5810 R; Eppendorf, Milano, Italy) at 2,683 $\times g$ at $4{ }^{\circ} \mathrm{C}$ for $30 \mathrm{~min}$. The supernatants and the pellets were separated and stored at $-20{ }^{\circ} \mathrm{C}$ for subsequent analysis. As blank experiments, in order to verify protein extractions for every solution in absence of enzymes, all the above experiments were also carried out in the same conditions, but without the addition of enzymes.

\section{Protein extraction yield}

The supernatants and pellets collected after the enzymatic extraction were subjected to a Kjeldahl analysis in order to determine the nitrogen content and calculate the nitrogen mass balance. The yield of protein extraction was calculated by comparing the amount of nitrogen in the supernatant (assumed to be completely due to protein nitrogen) to the total protein nitrogen in the insects (data provided from amino acid analysis). The amount of nitrogen due to the added enzymes, being negligible $(<1 \%)$, was not considered. On the other side, the contribute of salts containing nitrogen, whenever present in the extraction systems, was considered and subtracted when necessary.

\section{Degree of hydrolysis}

The degree of hydrolysis (DH), which is defined as the percentage of cleaved peptide bonds on total peptide bonds, was calculated using o-phtaldialdehyde (OPA) method described by Spellman et al. (2003) with some modifications (Butrè et al., 2012). The hydrolysed samples were diluted in a $2 \%(\mathrm{w} / \mathrm{v})$ sodium dodecyl sulfate, stirred for $20 \mathrm{~min}$ and stored at $4{ }^{\circ} \mathrm{C}$ overnight before the assay. The OPA/ NAC (N-acetyl-cysteine) reagent $(100 \mathrm{ml})$ was prepared by combining $10 \mathrm{ml}$ of $50 \mathrm{mM}$ OPA (in methanol) and 10 $\mathrm{ml}$ of NAC $50 \mathrm{mM}, 5 \mathrm{ml}$ of $20 \%$ (w/v) SDS, and $75 \mathrm{ml}$ of

Table 1. Optimum condition of $\mathrm{pH}$ and temperature for the enzymes tested.

$\begin{array}{llll}\text { Enzyme } & \mathbf{p H} & \text { Temperature } & \text { Solution buffer } \\ & & & \\ \text { PBL } & & 60^{\circ} \mathrm{C} & \mathrm{Na}_{2} \mathrm{HPO}_{4} 10 \mathrm{mM} \\ \text { Dispase I } & 7.5 & 37^{\circ} \mathrm{C} & \mathrm{CH}_{3} \mathrm{COONa} 10 \mathrm{mM},\left(\mathrm{CH}_{3} \mathrm{COO}\right)_{2} \mathrm{Ca} 5 \mathrm{mM} \\ \text { Pepsin } & 7.3 & 37^{\circ} \mathrm{C} & \mathrm{HCl}_{10 \mathrm{mM}} \\ \text { Pancreatin } & 3.0 & 37^{\circ} \mathrm{C} & \mathrm{NH}_{4} \mathrm{HCO}_{3} 25 \mathrm{mM}, \mathrm{CaCl}_{2} 2.5 \mathrm{mM} \\ \text { Trypsin } & 7.8 & 37^{\circ} \mathrm{C} & \mathrm{NH}_{4} \mathrm{HCO}_{3} 25 \mathrm{mM}, \mathrm{CaCl}_{2} 2.5 \mathrm{mM} \\ \text { Bromelain } & 7.8 & 50^{\circ} \mathrm{C} & \mathrm{Na}_{2} \mathrm{HPO}_{4} 10 \mathrm{mM} \\ \text { Papain } & 7.0 & 60^{\circ} \mathrm{C} & \mathrm{Na}_{2} \mathrm{HPO}_{4} 10 \mathrm{mM}, \mathrm{EDTA} 2 \mathrm{mM}, \mathrm{DL} \text {-cystin } 4 \mathrm{mM}\end{array}$

${ }^{1}$ Protease from Bacillus licheniformis. 
borate buffer $(0.1 \mathrm{M}, \mathrm{pH}=9.5)$. The reagent was covered with aluminium foil, to protect from light, and stirred for at least $1 \mathrm{~h}$ before use. The OPA assay was carried out by the addition of $20 \mu \mathrm{l}$ of sample (or standard) to $2.4 \mathrm{ml}$ of OPA/ NAC reagent in a $5 \mathrm{ml}$ of a plastic Eppendorf. Before the analysis, the samples were centrifuged at room temperature for $10 \mathrm{~min}$ at $280 \times \mathrm{g}$. The absorbance of the obtained solution was measured at $340 \mathrm{~nm}$ with Jasco B-530 UVVis-spectrophotometer (Jasco, Oklaoma City, OK, USA) against a control cell containing the reagent and $20 \mu$ of the buffer used for the sample. The intrinsic absorbance of the samples was measured before OPA addition and subtracted. The standard curve was prepared using L-isoleucine (0-2 $\mathrm{mg} / \mathrm{ml})$. The DH was calculated as the ratio between the free nitrogen groups after hydrolysis and the total nitrogen groups: $\mathrm{DH} \%=($ Nfree $/$ Ntotal $) \times 100$. The former value was calculated by the OPA reactivity, whereas the total moles of nitrogen atoms involved in peptide bonds before hydrolysis were calculated by the total grams of proteins, obtained from total amino acids analysis, divided by the average of residual amino acids molecular mass (Mw 110). The average peptide chain length was obtained by the following equation: 100 / DH\%, according to Adler-Nissen (1986)

\section{Free amino acid analysis}

The free amino acids (FAA) analysis was carried out on insect samples, and on the supernatants obtained after the enzymatic assisted extraction. $0.5 \mathrm{~g}$ of ground $\mathrm{HI}$ and $\mathrm{AD}$ were suspended in $5 \mathrm{ml}$ of water and mixed with 340 $\mu \mathrm{l}$ of $5 \mathrm{mM}$ norleucine (in $\mathrm{HCl} 0.1 \mathrm{M}$ ) for $2 \mathrm{~h}$. The volume was then brought to $10 \mathrm{ml}$ with the addition of deionised water and then centrifuged for $30 \mathrm{~min}$ at $4{ }^{\circ} \mathrm{C}$ at $2,683 \times g$. As far as the analysis of FAA in supernatants, they were filtered on a $0.45 \mu \mathrm{m}$ nylon filter membrane and collected. $100 \mu \mathrm{l}$ of supernatants were mixed with $34 \mu \mathrm{l}$ of $5 \mathrm{mM}$ Norleucine (in $\mathrm{HCl} 0.1 \mathrm{M}$ ) and the volume brought to 1 $\mathrm{ml}$ with deionised water. Quantification was performed against a set of standard solutions. $10 \mu \mathrm{l}$ of samples, 70 $\mu \mathrm{l}$ of borate buffer and $20 \mu \mathrm{l}$ of reconstituted AccQ Tag reagent (Waters) were mixed and then heated at $55^{\circ} \mathrm{C}$ for $10 \mathrm{~min}$. The derivatised samples were diluted with $100 \mu \mathrm{l}$ of deionised water before injecting in the UPLC/ESI-MS system. The conditions of analysis were the same described for Trp analysis.

\section{Process scale up}

Process scale up was performed on AD larvae by using protease from B. licheniformis, with slight modification of the protocol previously described in order to adjust for the larger scale. Specifically, $1.5 \mathrm{~kg}$ of freeze-dried (Christ, gamma 1-16 LSC, $36 \mathrm{~h}$ ) ground larvae were mixed with $7.5 \mathrm{l}$ of the specific buffer solution (Table 1) in a $10 \mathrm{l}$ flask, at $\mathrm{pH}=7.5$ and pre-heated at $60^{\circ} \mathrm{C}$. Before the addition of the enzyme, the mixture was homogenised in an incubator at $130 \mathrm{rpm}$ for $30 \mathrm{~min}$, while checking the $\mathrm{pH}$ (ProfiLine pH 3310, WTW, Xylem Analytics LLC, Weilheim in Oberbayern, Germany). The $\mathrm{pH}$ fluctuations were adjusted adding concentrated $\mathrm{NaOH}$. Next, $0.25 \%(\mathrm{w} / \mathrm{w})$ of enzyme was added and the hydrolysis was performed for $180 \mathrm{~min}$. After this time, the mixture was heated at $90^{\circ} \mathrm{C}$ for $5 \mathrm{~min}$ for the endogenous and exogenous enzymes inactivation and subsequently centrifuged at $4{ }^{\circ} \mathrm{C}$ for $30 \mathrm{~min}$ at $3,220 \times g$. The supernatant was separated from the pellet and the lipid upper layer using a $500 \mu \mathrm{m}$ sieve and freeze-dried for the further analysis. The hydrolysis reaction was performed in duplicate and the hydrolysates characterised in terms of proximate composition and $\mathrm{DH} \%$ as previously described.

\section{Statistical analysis}

All experiments were carried out in triplicate. Data are expressed as the mean \pm standard deviation. Statistical analysis was performed using SPSS version 21.0 (SPSS Inc., Chicago, IL, U.S.A.) and STATISTICA 12 of StatSoft. Significant differences were compared at a level of $P<0.05$.

\section{Results and discussion}

The goal of this study was to produce protein hydrolysates starting from $\mathrm{AD}$ and $\mathrm{HI}$, by using proteolytic enzymes in order to increase the efficiency of extraction, with the final aim to obtain protein hydrolysates with potentiality for feed or food applications. Different enzymes, of microbial, vegetable ad animal origin, were employed, in order to explore the different extractant abilities, and the characteristics of the final hydrolysed mixtures obtained. Finally, the most promising insect-enzyme combination was chosen for a proof-of-concept scale up.

\section{Insects composition}

The proximate composition of $\mathrm{HI}$ and $\mathrm{AD}$ larvae, in terms of dry matter, ash, lipid, protein and chitin was first determined (Table 2).

Table 2. Proximate composition of Hermetia illucens and Alphitobius diaperinus. ${ }^{1}$

\begin{tabular}{lcc} 
Composition (\%) & H. illucens & A. diaperinus \\
& & \\
Dry matter (DM) & $29.5 \pm 0.3$ & $33.6 \pm 0.3$ \\
Total nitrogen (on DM) & $9.1 \pm 0.5$ & $10.3 \pm 0.4$ \\
Proteins, from total amino acids (on DM) & $41.8 \pm 2.8$ & $53.9 \pm 5.4$ \\
Lipid (on DM) & $20.7 \pm 0.2$ & $29.6 \pm 0.4$ \\
Chitin (on DM) & $7.2 \pm 0.3$ & $4.6 \pm 0.1$ \\
Ash (on DM) & $11.95 \pm 0.01$ & $4.24 \pm 0.03$ \\
\hline \multirow{2}{*}{} & \\
\hline \multirow{2}{*}{ Value are expressed on dry matter basis and are the results of three replicate } \\
analysis.
\end{tabular}


From the chemical composition analysis, AD resulted to have a higher amount of lipid in comparison to HI, whereas HI was characterised by a higher level of chitin and ash. In case of insect biomasses, total nitrogen is not a useful information for the calculation of protein content: indeed nitrogen originates not only from proteins and other minor sources (e.g. nucleic acids, phospholipids, and ammonia), but also (in a non-negligible way) from chitin, which is the main component of the exoskeleton. In order to precisely calculate the specific amount of protein in both insects, total amino acids analysis was then performed (Table 3). HI and $\mathrm{AD}$ had both a high protein content, with $\mathrm{AD}$ containing more proteins than $\mathrm{HI}$. The protein content resulted to be higher for both insect than what reported by Caligiani et al. (2018) and Janssen et al. (2017), whereas lipid and ash were present in a comparable amount. The missing dry matter is likely represented by carbohydrates (chitin excluded), which in these insect species are between 15 and $21 \%$ on dry matter (Janssen et al., 2017).

Both insects contained good quality proteins: the essential amino acid profile for both usually largely exceeded the requirement proposed for human nutrition, except in the case of sulphur AAs and tryptophan, resulting to be the limiting AAs. The samples here analysed had, to equal protein content, a slightly lower amount of essential amino acids than what reported by Caligiani et al. (2018), Janssen et al. (2017) and Leni et al. (2019) (about 10\% less for both species). The differences in the AA profile could be related to the different substrates used to feed insects (Gligorescu et al., 2018; Meneguz et al., 2018; Ramos-Elorduy et al., 2002).

From this AA composition it was possible to determine the conversion factor from nitrogen to protein, to be used for Kjeldahl analysis, which resulted in $5.5 \pm 0.1$ for $\mathrm{HI}$ and $5.67 \pm 0.03$ for $\mathrm{AD}$. The $\%$ of proteinaceous nitrogen on total dry matter was then recalculated as $7.6 \pm 0.4 \%$ for $\mathrm{HI}(84 \%$ of the total nitrogen) and $9.5 \pm 0.9 \%$ for $\mathrm{AD}$ ( $87 \%$ of the total nitrogen). These values were used in the next experiments to compare the protein extractability with the different enzymes tested.

The $\%$ of nitrogen derived from chitin could also be backcalculated by considering the specific conversion factor, which vary from 14.5 to 11.5 , assuming a fully acetylated or deacetylated glucosamine (Caligiani et al., 2018). Chitinderived nitrogen was then calculated to be between 0.5 and $0.7 \%$ in $\mathrm{HI}$, and between 0.3 and $0.4 \%$ in $\mathrm{AD}$. The remaining nitrogen $(0.9 \%$ in $\mathrm{HI}, 10 \%$ of the total, and $0.5 \%$ in $\mathrm{AD}, 5 \%$ of the total) is to be ascribed to sources other than proteins and chitin.

Table 3. Total amino acid (AA) content for Hermetia illucens and Alphitobius diaperinus expressed as $\mathrm{g} / 100 \mathrm{~g}$ total protein (calculated from total amino acids) and compared with the FAO/WHO standard protein (2001). ${ }^{1}$

\begin{tabular}{|c|c|c|c|}
\hline Essential AA (g/100 g protein) & H. illucens & A. diaperinus & Reference protein (FAO/WHO 2001) \\
\hline His & $3.3 \pm 0.2$ & $3.3 \pm 0.3$ & 1.5 \\
\hline Thr & $3.77 \pm 0.06$ & $3.89 \pm 0.04$ & 2.3 \\
\hline Val & $5.5 \pm 0.2$ & $5.5 \pm 0.3$ & 3.9 \\
\hline Lys & $5.8 \pm 0.2$ & $6.3 \pm 0.4$ & 4.5 \\
\hline lle & $3.9 \pm 0.2$ & $4.1 \pm 0.2$ & 3.0 \\
\hline Leu & $6.3 \pm 0.1$ & $6.3 \pm 0.3$ & 5.9 \\
\hline Trp & $0.7 \pm 0.1$ & $0.45 \pm 0.04$ & 0.6 \\
\hline Phe + Tyr & $10.1 \pm 0.3$ & $11.6 \pm 0.5$ & 3.8 \\
\hline Phe & $3.7 \pm 0.2$ & $4.1 \pm 0.2$ & \\
\hline Tyr & $6.4 \pm 0.1$ & $7.5 \pm 0.3$ & \\
\hline Cys + Met & $1.9 \pm 1.2$ & $2.1 \pm 0.4$ & 2.2 \\
\hline Cys & $0.6 \pm 0.4$ & $0.96 \pm 0.09$ & \\
\hline Met & $1.3 \pm 0.8$ & $1.1 \pm 0.3$ & \\
\hline \multicolumn{4}{|l|}{ Non-essential AA } \\
\hline $\operatorname{Arg}$ & $9.8 \pm 0.9$ & $7.1 \pm 0.8$ & \\
\hline Ala & $8.12 \pm 1.02$ & $9.96 \pm 4.07$ & \\
\hline Gly & $4.7 \pm 0.2$ & $4.1 \pm 0.3$ & \\
\hline Ser & $3.7 \pm 0.1$ & $3.6 \pm 0.2$ & \\
\hline Pro & $5.2 \pm 0.1$ & $6.05 \pm 0.37$ & \\
\hline Glu/Gln & $11.8 \pm 1.1$ & $12.4 \pm 0.6$ & \\
\hline Asp/Asn & $8.5 \pm 0.4$ & $8.1 \pm 0.4$ & \\
\hline
\end{tabular}




\section{Lab scale enzymatic assisted extraction and protein extraction yield}

The enzymatic assisted extraction was performed, at lab scale, with seven different proteolytic enzymes: papain and bromelain (vegetal proteases), protease from PBL, dispase (bacterial proteases), pepsin, trypsin and pancreatin (animal proteases). The hydrolysis was performed in all cases overnight, with an enzyme/substrate ratio of 1:100 $(\mathrm{w} / \mathrm{w})$, at the optimal $\mathrm{pH}$ and temperature for each enzyme (Table 1). The long reaction time was needed in order to make sure to obtain an end point proteolysis reaction. The protein extraction yield was evaluated by Kjeldahl analysis, in order to determine the solubilised nitrogen as compared to the total protein nitrogen (see section above).

The extraction yield is reported in Figure 1, as a measure of the ability of proteolytic enzymes to extract and solubilise proteins. The yields obtained with the same solutions, but without enzymes, are also reported. Even in absence of enzymes, insect proteins were partially solubilised in the conditions applied, but almost never exceeding 50\% extraction yield. These figures were higher than what was reported by Hall et al. (2017) for cricket (about 20\%), likely due to the different insect species and the longer extraction times in our case, and the presence of different buffers at different $\mathrm{pH}$. On the other side, these results are in line with our previous work, where an analogue yield (43\%) was reached when extracting albumins and globulins from HI (Caligiani et al., 2018). With the addition of enzymes, the amount of solubilised proteins showed an average $20 \%$ increase, supporting the enzymatic hydrolysis as an efficient way to extract and solubilise proteins from AD and HI.

\section{Degree of hydrolysis of protein hydrolysates}

The degree of hydrolysis (DH\%), defined as the percentage of cleaved peptide bonds in the protein hydrolysates, was determined on the solubilised protein fractions after the enzymatic extractions. The free amino groups, i.e. the cleaved peptide bonds, were determined by the OPA assay. They were then related to the total nitrogen groups involved in peptide bond (before hydrolysis) in order to calculate the $\mathrm{DH} \%$. The higher the $\mathrm{DH}$ value, the higher the number of peptide bonds cleaved, and the shorter the peptides. The average peptide chain length can be calculated from DH\% according to Adler-Niessen (1986). DH\% and average peptide chain length in the protein hydrolysates are reported in Table 4 . The DH\% of the solutions obtained without enzymes were not measured, since in a previous paper they have already been demonstrated to be very low (Caligiani et al., 2018). This also indicates a lack of a consistent endogenous protease activity.

Protein hydrolysates produced from $\mathrm{HI}$ had a $\mathrm{DH} \%$ included between 3 and 18\%, whereas for AD this range was between 7 to $23 \%$. The different DH\% obtained for the same species confirmed that the proteolytic activity of the different enzymes is different on the same substrates, due to the different enzyme specificities. In the case of $\mathrm{HI}$, the DH\% of the hydrolysate with papain presented the lowest value (3.3\%), whereas trypsin yielded the hydrolysate with the highest DH (18\%). For AD, the highest DH\% was obtained performing the hydrolysis with bromelain (23\%), whereas the lowest proteolytic activity was observed for papain (7\%). In few cases, a pretty low DH\% was observed, which is quite surprising, considering the overnight reaction. This might be due to enzyme specificity (which limits the maximum
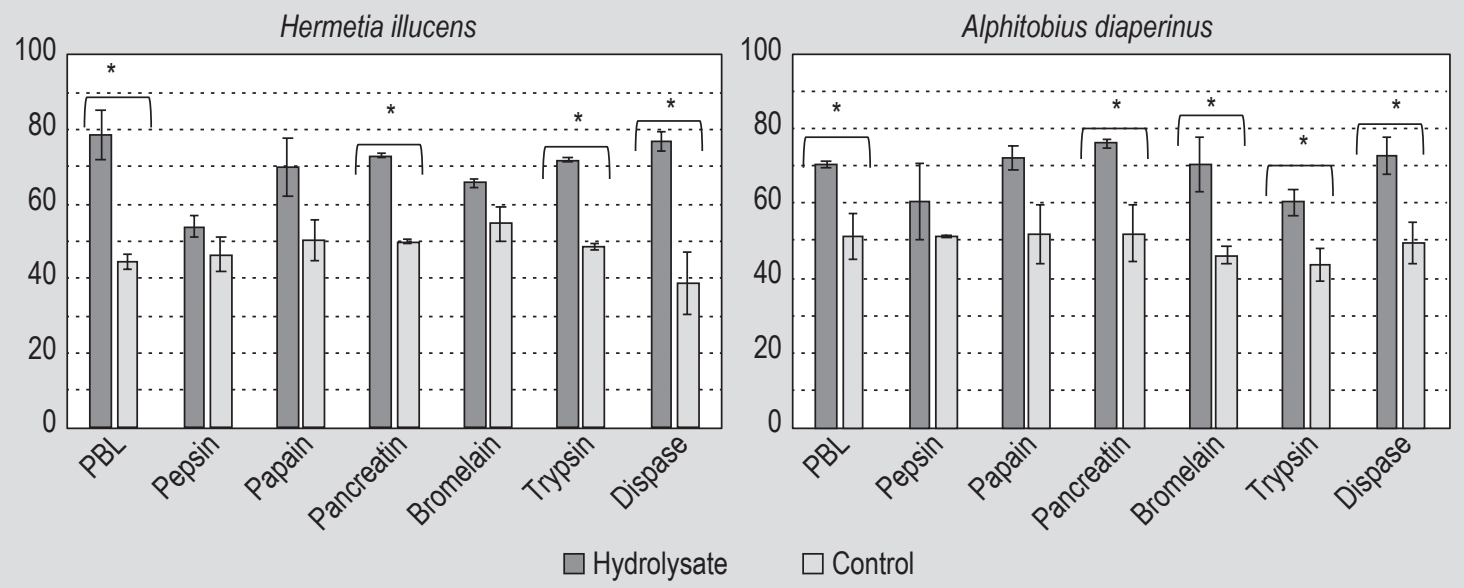

Figure 1. Protein extraction yields obtained by performing enzymatic hydrolysis with seven different enzymes to ground Hermetia illucens (on left) and Alphitobius diaperinus (on right). The protein extraction yields for the blanks (buffers with no enzymes) are also reported. The results are the mean of three separate hydrolysis experiments. Asterics indicate significant differences $(P<0.05)$ in protein extraction yields between the enzymatic hydrolysates and the corresponding blanks. 
Table 4. Degree of hydrolysis (DH, \%) and average peptide chain length of protein hydrolysates obtained from Hermetia illucens and Alphitobius diaperinus larvae subjected to different enzymatic extraction.

\begin{tabular}{|c|c|c|c|c|}
\hline \multirow[t]{2}{*}{ Enzyme } & \multicolumn{2}{|c|}{ H. illucens } & \multicolumn{2}{|c|}{ A. diaperinus } \\
\hline & $\mathrm{DH} \%$ & $\begin{array}{l}\text { Average peptide chain length } \\
\text { (100/DH\%, uncertainty included in } \\
\text { the range) }\end{array}$ & $\mathrm{DH} \%$ & $\begin{array}{l}\text { Average peptide chain length } \\
\text { (100/DH\%, uncertainty included in } \\
\text { the range) }\end{array}$ \\
\hline $\mathrm{PBL}^{1}$ & $10.4 \pm 2.3$ & $8-12$ & $21.8 \pm 0.5$ & $4-5$ \\
\hline Pepsin & $10.2 \pm 1.1$ & $9-11$ & $15.8 \pm 3.4$ & $5-8$ \\
\hline Papain & $3.3 \pm 2.1$ & $19-83$ & $7.0 \pm 0.9$ & $6-13$ \\
\hline Pancreatin & $8.8 \pm 4.6$ & $7-24$ & $17.6 \pm 3.1$ & $5-7$ \\
\hline Bromelain & $13.3 \pm 1.5$ & $7-8$ & $23.1 \pm 5.8$ & $3-6$ \\
\hline Trypsin & $18.2 \pm 0.5$ & $5-6$ & $21.9 \pm 5.5$ & $4-6$ \\
\hline Dispase I & $17.3 \pm 0.2$ & 6 & $15.9 \pm 1.2$ & $6-7$ \\
\hline
\end{tabular}

amount reachable), the cross inhibition exerted by the generated peptides, the presence of specific inhibitors. Purschke et al. (2018b) reported, with the same enzyme/ substrate ration, a comparable $\mathrm{DH} \%$ for the hydrolysis of migratory locust with PBL (19 to $31 \%$ from 8 to 24 h of hydrolysis), but a higher $\mathrm{DH} \%$ for the one with papain $(13 \%$ for only 8 h of hydrolysis). Hall et al. (2017) performed an enzymatic extraction on tropical banded crickets with PBL, reporting a higher DH (36\% for 90 min of hydrolysis with $0.5 \%$ of enzyme). Thus, ours and literature data also suggests that the same enzyme can yield different degrees of hydrolysis, when applied to different insect species, even if the different ways for calculating the DH\% found in literature hamper a direct comparison between experiments.

The average peptide chain length in the hydrolysate, obtained from the DH\% (Adler-Nissen, 1986), can give information not only for the physicochemical and functional properties of the protein hydrolysates, but also for their potential hypo allergenicity (Adler-Nissen and Sejr Olsen, 1979). The hydrolysates from HI had an average peptide length ranging from 5-8 residues (with trypsin, dispase I and bromelain) to much larger peptides (with papain and pancreatin), whereas the same figures for AD where mostly in the range of 3-8 residues (all enzymes but papain). This is not of a secondary importance, since as reported by Nagodawithana et al. (2008), an average molecular weight lower than 1,500 Da (about 14 AA residues) can reduce the allergenicity property of a food product. However, these results are only to be considered as suggesting a potential hypoallergenicity, and true hypoallergenicity will have to be assessed by showing the absence of orally sensitisation after animal administration (EC, 2006).

\section{Free amino acids profile of protein hydrolysates}

The hydrolysates and the untreated larvae were also analysed in order to evaluate the FAA profile: the results are shown in Supplementary Material (Table S1 for the fractions originating from $\mathrm{AD}$ and Table $\mathrm{S} 2$ for the fractions originating from $\mathrm{HI}$ ). The total FAA contents in untreated insect was very low $(4.8 \mathrm{mg} / \mathrm{g}$ of dry $\mathrm{HI}$ and $5.1 \mathrm{mg} / \mathrm{g}$ of dry AD). This amount significantly increased after the enzymatic hydrolysis, ranging from $70.6 \mathrm{mg}$ to $152.2 \mathrm{mg} / \mathrm{g}$ of dry $\mathrm{HI}$ and from $76.7 \mathrm{mg}$ to $126.6 \mathrm{mg} / \mathrm{g}$ of dry AD. The predominant FAA in all the hydrolysates was Ala, for both $\mathrm{AD}$ and $\mathrm{HI}$, ad also Leu only for AD. The amount of FAA in the supernatants, compared to the total protein (deduced from Kjeldahl) also allowed to estimate the amount of amino acids in bound form (Figure 2). The HI extracts obtained with dispase I gave the highest relative proportion of FAA (30\% of total proteins were extracted as FAAs) whereas pepsin the lowest (16\% of total proteins extracted as FAAs). Instead, papain acted on $\mathrm{AD}$ releasing the lowest relative amount of FAA ( $12 \%$ of total proteins extracted as FAAs), while PBL the highest amount (23\%). Also this data demonstrates how the same enzymes act differently on the two different species of insects.

For both insect species a weak positive correlation emerged between DH\% and FAAs ( $\mathrm{r}=0.614$ for HI hydrolysate and $\mathrm{r}=0.584$ for $\mathrm{AD}$ hydrolysate). This means that, in general, high DH correlates with the release of high amount of AAs in free form. Strong outliers for this trend were the AD hydrolysate with trypsin (high $\mathrm{DH}$, but low amount of free AAs) and HI hydrolysate with papain (low DH, but high amount of free AAs). In the former case, this means that the enzyme has a preference to cut on large 


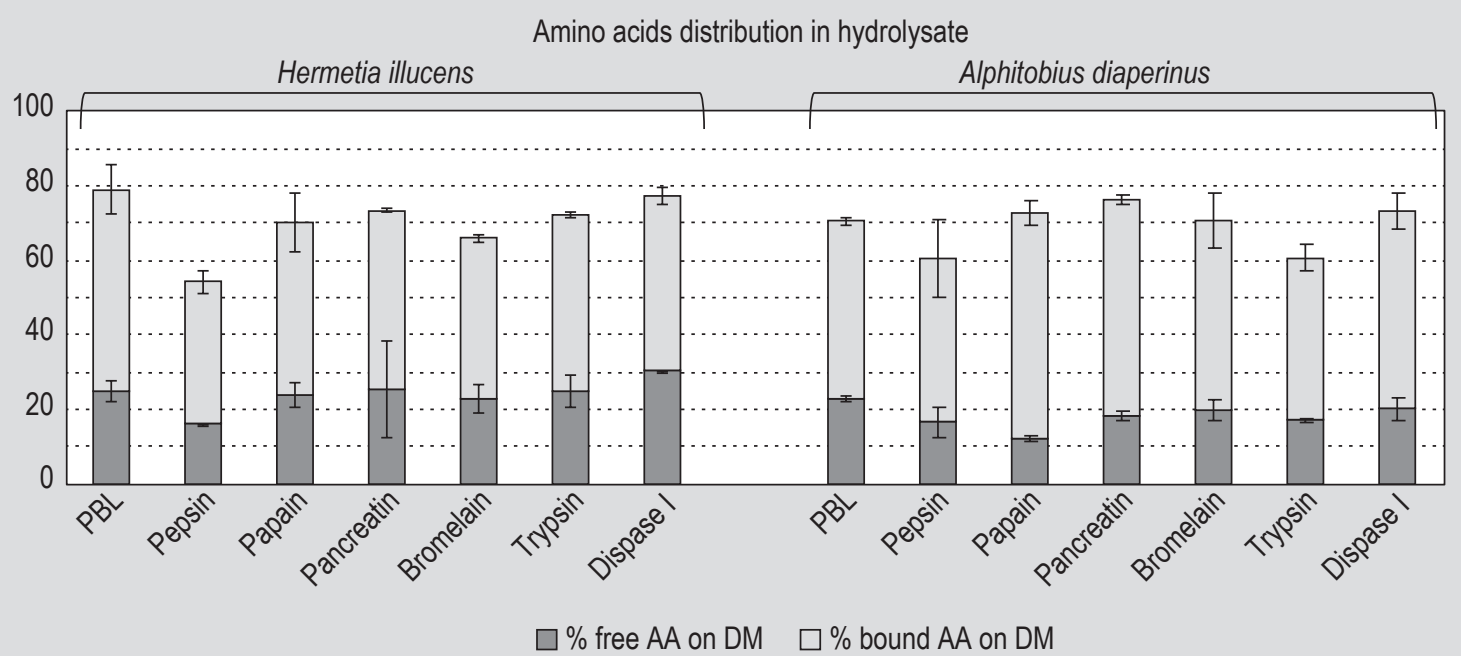

Figure 2. Distribution of bound and free amino acids in the supernatant after enzymatic hydrolysis. The full bar indicates the protein extraction yield (as reported in Figure 1) in the supernatant. The darker part of the bar indicates the amino acids present in free form and the light part of the bar the amino acids involved in peptide bond (calculated by difference).

peptides/ intact proteins, leaving small peptides relatively untouched, whereas in the latter case the opposite happens, with enzymes preferentially cleaving on small peptides rather than on large peptides/intact proteins.

The percentage distribution of FAAs essentially is consistent with the one observed for total amino acids and reported in Table 3 (with the only exception of cysteine released with trypsin). This indicates that FAA are released in the medium, in all cases, in a way which is correlated to their abundance in the proteins. The enzymes here tested are all endopeptidases, excepted for pancreatin which is a mixture of endopeptidase and exopeptidase, with a predominance of the first one. FAA release could be due either to pure chemical hydrolysis from the peptides formed, or by specific and non-specific cleavage of the endopeptidase tested. Furthermore, the proteolytic enzymes could produce reasonably high level of essential amino acids in free form (about 10\% of their total amount in the insect biomass). The high levels of free essential amino acids (in theory more digestible than bound ones) enhance the value and potential of insect hydrolysates for feed and/or food formulation.

\section{Process scale up}

In order to demonstrate, as proof of concept, the scalability of the process to industrial production, the most promising insect-enzyme combination was adjusted for a reaction scale up. The reaction time was reduced as compared to the lab scale, according to energy-saving considerations, and on the assumption that, after reaching the plateau phase, most of the proteins have already been extracted in solution. For this reason, the insect-enzyme combination giving the highest $\mathrm{DH} \%$ at lab scale was chosen. This also allowed for a reduction of the enzyme/substrate ratio, and of the volume of the buffer (also useful for reduction of environmental impact), resulting in an increased enzyme concentration as compared to the lab scale. The hydrolysis was thus performed with PBL on AD larvae. Before the enzymatic extraction, AD larvae were freeze-dried in order to improve the insect grinding. The hydrolysis was then performed on $1.5 \mathrm{~kg}$ of dried and ground larvae for $3 \mathrm{~h}$, at optimal temperature and $\mathrm{pH}$ conditions. The obtained hydrolysate was freeze-dried, yielding $600 \mathrm{~g}$ of protein hydrolysate. This protein hydrolysate was then characterised in order to define the proximate composition (Table 5).

Table 5. Bulk composition expressed on dry matter (after freeze drying $=93 \%$ ) of protein hydrolysate obtained from Alphitobius diaperinus (AD) hydrolysis $\left(3 \mathrm{~h}, 60^{\circ} \mathrm{C}, \mathrm{pH}=7.5\right)$ with the protease from Bacillus licheniformis (PBL). Degree of hydrolysis (DH\%) and protein extraction yield are also reported. Results are the mean of three separate analysis conducted on the two reactions performed as replicates.

$\begin{array}{llllll}\text { Sample upscaled } & \text { Protein } \% & \text { Lipid } \% & \text { Ash } \% & \text { DH } \% & \text { Protein extraction yield \% } \\ \text { AD+PBL } & 62.1 \pm 0.3 & 17.3 \pm 2.6 & 9.1 \pm 0.6 & 9.8 \pm 0.7 & 42.1 \pm 4.3\end{array}$


The hydrolysate resulted to be rich in protein (62.1 $\pm 0.3 \%)$, with some lipid and ash. A lower extraction yield and a lower DH \% was obtained as compared to the lab trials, as a result of the protocol adjustments applied (amount of sample, buffer, substrate and time). Although certainly more optimisation is needed, this experiment demonstrated the possibility of an efficient production of a protein hydrolysate from insects, which could be used as insectbased ingredients for feed and food formulations.

\section{Conclusions}

The enzymatic-assisted protein extraction here presented clearly represents an effective method to extract and isolate protein from two different edible insects, $\mathrm{HI}$ and AD. In the present work the different proteolytic activity of seven enzymes was studied, by evaluating the characteristics of protein hydrolysate produced at a laboratory scale: yields of extraction, protein integrity and FAA composition. This is the first time that several enzymes are tested and compared on these two insect species, and that the protein hydrolysates obtained underwent such a detailed assessment for their molecular composition.

Proteases were able to extract protein from insects in form of peptides and FAA, preserving their quality and making them more accessible for their future use as feed/ food supplements. Protein hydrolysate, as opposed to intact protein, are more rapidly digested and absorbed, and, also important, could be potentially hypoallergenic. Furthermore, as a proof of concept, the potential scale up of the process was performed, by focusing on the most promising insect-enzyme combination. Starting from 1.5 $\mathrm{kg}$ of dry AD larvae, $600 \mathrm{~g}$ of dry hydrolysate containing more than $60 \%$ proteins, in form of peptides and FAA, were produced. Further investigations are needed in order to optimise the process for industrial production of insectbased ingredients for feed and food formulations, but the processes here presented have the potential to produce protein hydrolysates in an environmentally friendly way, even if a full LCA assessment on a perfectly optimised protocol will be needed to verify this feature.

\section{Founding sources}

This project received funding from the Bio Based Industries Joint Undertaking under the European Union's Horizon 2020 research and innovation programme under grant agreement no. 720715 (InDIRECT project).

\section{Conflict of interest}

The authors declare that they have no conflict of interest.

\section{Supplementary material}

Supplementary material can be found online at https://doi. org/10.3920/JIFF2019.0037.

Table S1. Free amino acids composition of hydrolysates from Alphitobius diaperinus using commercial protease under optimum conditions. Results are expressed as $\mathrm{mg} / \mathrm{g}$ of dry insects employed for the hydrolysis. Results are the mean of three separate hydrolysis experiments. Different letters in the same row show significant differences $(P<0.05)$.

Table S2. Free amino acids composition of hydrolysates from Hermetia illucens using commercial protease under optimum conditions. Results are expressed as $\mathrm{mg} / \mathrm{g}$ of dry insects employed for the hydrolysis. Results are the mean of three separate hydrolysis experiments. Different letters in the same row show significant differences $(P<0.05)$.

\section{References}

Adler-Nissen J., 1986. Enzymic hydrolysis of food proteins. Elsevier, New York, NY, USA, 427 pp.

Adler-Nissen, J. and Sejr Olsen, H., 1979. The influence of peptide chain length on taste and functional properties of enzymatically modified soy protein. In: Pour-El, A. (ed.) Functionality and protein structure. Vol. 92. ACS Symposium Series, Washington, DC, USA, pp. 125-146.

Ahmadifard, N., Murueta, J.H., Abedian-Kenari, A., Motamedzadegan, A. and Jamali, H., 2016. Comparison the effect of three commercial enzymes for enzymatic hydrolysis of two substrates (rice bran protein concentrate and soy-been protein) with SDS-PAGE. Journal of Food Science and Technology 53: 1279-1284. https:// doi.org/10.1007/s13197-015-2087-6

Association of Official Agricultural Chemists (AOAC), 2002. Official method of analysis (16 ${ }^{\text {th }}$ Ed.). AOAC, Washington, DC, USA, 711 pp.

Butrè, C.I., Wierenga, P.A. and Gruppen H., 2012. Effects of ionic strength on the enzymatic hydrolysis of diluted and concentrated whey protein isolate. Journal of Agricultural and Food Chemistry 60: 5644-5651. https://doi.org/10.1021/jf301409n

Caligiani, A., Marseglia, A., Leni, G., Baldassarre, S., Maistrello, L., Dossena, A. and Sforza, S., 2018. Composition of black soldier fly prepupae and systematic approaches for extraction and fractionation of proteins, lipids and chitin. Food Research International 105: 812820. https://doi.org/10.1016/j.foodres.2017.12.012

Chen, X.M., Feng, Y. and Hong, Z., 2010. Review of the nutritive value of edible insects. In: Durst, P., Johnson, D., Leslie, R. and Shono, K. (eds.) Forest insects as food: humans bite back. Food and Agriculture Organization of the United Nations (FAO), Bangkok, Thailand, pp. 85-92.

D'Hondt, E., Soetemans, L., Bastiaens, L., Maesen, M., Jespers, V., Van den Bosch, B., Voorspoels, S. and Elst, K., 2020. Simplified determination of the content and average degree of acetylation of chitin in crude black soldier fly larvae samples. Carbohydrate Research 488: 107899. https://doi.org/10.1016/j.carres.2019.107899 
Del Mar Contreras, M., Lama-Muñoz, A., Gutiérrez-Pérez, J.M., Espínola, F., Moya, M. and Castro, E., 2019. Protein extraction from agri-food residues for integration in biorefinery: potential techniques and current status. Bioresource Technology 280: 459-477. https:// doi.org/10.1016/j.biortech.2019.02.040

Delgado-Andrade, C., Rufián-Henares, J., Jiménez-Pérez, S. and Morales, F.J., 2006. Tryptophan determination in milk-based ingredients and dried sport supplements by liquid chromatography with fluorescence detection. Food Chemistry 98: 580-585. https:// doi.org/10.1016/j.foodchem.2005.07.036

European Commission (EC), 2001. Regulation (EC) No 999/2001 of the European Parliament and of the Council of 22 May 2001 laying down rules for the prevention, control and eradication of certain transmissible spongiform encephalopathies. Official Journal of the European Union L 147: 1-40.

European Commission (EC), 2006. Commission Directive 2006/141/EC of 22 December 2006 on infant formulae and follow-on formulae and amending Directive 1999/21/EC. Official Journal of the European Union L 401: 1-33.

European Commission (EC), 2015. Regulation (EU) 2015/2283 of the European Parliament and of the Council of 25 November 2015 on novel foods, amending Regulation (EU) No 1169/2011 of the European Parliament and of the Council and repealing Regulation (EC) No 258/97 of the European Parliament and of the Council and Commission Regulation (EC) No 1852/2001. Official Journal of the European Union L 327: 1-22.

European Commission (EC), 2017. Commission Regulation (EU) 2017/893 of 24 May 2017 amending Annexes I and IV to Regulation (EC) No 999/2001 of the European Parliament and of the Council and Annexes X, XIV and XV to Commission Regulation (EU) No $142 / 2011$ as regards the provisions on processed animal protein. Official Journal of the European Union L 138: 92-116.

Food and Agriculture Organisation (FAO), 2009. FAO's directorgeneral on how to feed the world in 2050. Population and Development Review 35: 837-839. https://doi.org/10.1111/j.17284457.2009.00312.x

Food and Agriculture Organisation / World Health Organisation (FAO/ WHO), 2001. Human energy requirements. Report of a Joint FAO/ WHO/UNU Expert Consultation, October 17-24, 2001, Rome, Italy. Available at: http://www.fao.org/3/y5686e/y5686e00.htm

Gligorescu, A., Toft, S., Hauggaard-Nielsen, H., Axelsen, J.A. and Nielsen, S.A., 2018. Development, metabolism and nutrient composition of black soldier fly larvae (Hermetia illucens; Diptera: Stratiomyidae) in relation to temperature and diet. Journal of Insects as Food and Feed 4: 123-133. https://doi.org/10.3920/JIFF2017.0080

Hall, F.G., Jones, O.G., O’Haire, M.E. and Liceaga, A.M., 2017. Functional properties of tropical banded cricket (Gryllodes sigillatus) protein hydrolysates. Food Chemistry 224: 414-422. https://doi. org/10.1016/j.foodchem.2016.11.138

Janssen, R.H., Vincken, J.P., Van den Broek, L.A.M., Fogliano, V. and Lakemond, C.M.M., 2017. Nitrogen-to-protein conversion factors for three edible insects: Tenebrio molitor, Alphitobius diaperinus, and Hermetia illucens. Journal of Agricultural and Food Chemistry 65: 2275-2278. https://doi.org/10.1021/acs.jafc.7b00471
Leni, G., Caligiani, A. and Sforza, S., 2019. Killing method affects the browning and the quality of the protein fraction of black soldier fly (Hermetia illucens) prepupae: a metabolomics and proteomic insight. Food Research International 115: 116-125. https://doi. org/10.1016/j.foodres.2018.08.021

Li, Q., Zheng, L., Qiu, N., Cai, H., Tomberlin, J. and Yu, Z., 2011. Bioconversion of dairy manure by black soldier fly (Diptera: Stratiomyidae) for biodiesel and sugar production. Waste Management 31: 1316-1320. https://doi.org/10.1016/j. wasman.2011.01.005

Lynch, S.A., Mullen, A.M., O’Neill, E., Drummond, L. and Álvarez, C., 2018. Opportunities and perspectives for utilisation of coproducts in the meat industry. Meat Science 144: 62-73. https:// doi.org/10.1016/j.meatsci.2018.06.019

Meinlschmidt, P., Sussmann, D., Schweiggert-Weisz, U. and Eisner, P., 2015. Enzymatic treatment of soy protein isolates: effects on the potential allergenicity, technofunctionality, and sensory properties. Food Science and Nutrition 4: 11-23. https://doi.org/10.1002/ fsn3.253

Meneguz, M., Schiavone, A., Gai, F., Dama, A., Lussiana, C., Renna, M. and Gasco, L., 2018. Effect of rearing substrate on growth performance, waste reduction efficiency and chemical composition of black soldier fly (Hermetia illucens) larvae. Journal of the Science of Food and Agriculture 98: 5776-5784. https://doi.org/10.1002/ jsfa.9127

Mizani, M., Aminlari, M. and Khodabandeh, M., 2005. An effective method for producing a nutritive protein extract powder from shrimp-head waste. Food. Science and Technology International 11: 49-54. https://doi.org/10.1177/1082013205051271

Nagodawithana, T.W., Nelles, L. and Trivedi, N.B., 2008. Protein hydrolysates as hypoallergenic, flavors and palatants for companion animals. In Pasupuleti, V. and Demain, A. (eds.) Protein hydrolysates in biotechnology. Springer, Dordrecht, the Netherlands, pp. 191-207.

Nongonierma, A.B. and FitzGerald, R.J., 2017. Unlocking the biological potential of proteins from edible insects through enzymatic hydrolysis: a review. Innovative Food Science and Emerging Technologies 43: 239-252. https://doi.org/10.1016/j.ifset.2017.08.014 Purschke, B., Meinlschmidt, P., Horn, C., Rieder, O. and Jäger, H., 2018b. Improvement of techno-functional properties of edible insect protein from migratory locust by enzymatic hydrolysis. European Food Research and Technology 244: 999-1013. https:// doi.org/10.1007/s00217-017-3017-9

Purschke, B., Mendez Sanchez, Y.D. and Jäger, H., 2018a. Centrifugal fractionation of mealworm larvae (tenebrio molitor, L.) for protein recovery and concentration. Lebensmittel-Wissenschaft \& Technologie 89: 224-228. https://doi.org/10.1016/j.lwt.2017.10.057 Ramos-Elorduy, J., González, E.A., Hernández, A.R. and Pino, M.P., 2002. Use of Tenebrio molitor (Coleoptera: Tenebrionidae) to recycle organic wastes and as feed for broiler chickens. Journal of Economic Entomology 95: 214-20. https://doi.org/10.1603/0022-0493-95.1.214 Rumpold, B. and Schlüter, O., 2013. Potential and challenges of insects as an innovative source for food and feed production. Innovative Food Science and Emerging Technologies 17: 1-11. https://doi. org/10.1016/j.ifset.2012.11.005 
Russ, W. and Meyer-Pittroff, R., 2004. Utilizing waste products from the food production and processing industries. Reviews in Food Science and Nutrition 44: 37-41. https://doi. org/10.1080/10408690490263783

Sánchez-Muros, M., Haro, C., Sanz, A., Trenzado, C., Villareces, S. and Barroso, F., 2016. Nutritional evaluation of Tenebrio molitor meal as fishmeal substitute for tilapia (Oreochromis niloticus) diet. Aquaculture Nutrition 22: 943-955. https://doi.org/10.1111/ anu.12313

Smetana, S., Palanisamy, M., Mathys, A. and Heinz, V., 2016. Sustainability of insect use for feed and food: life cycle assessment perspective. Journal of Cleaner Production 137: 741-751. https:// doi.org/10.1016/j.jclepro.2016.07.148

Soetemans, L., Uyttebroek, M., D’Hondt, E. and Bastiaens, L., 2019. Use of organic acids to improve fractionation of the black soldier fly larvae juice into lipid and protein enriched fractions. European Food Research and Technology 245: 2257-2267. https://doi.org/10.1007/ s00217-019-03328-7

Sosa, D.A.T. and Fogliano, V., 2017. Potential of insect-derived ingredients for food applications. In Shields, V.D.C. (ed.) Potential of insect-derived ingredients for food applications, insect physiology and ecology. IntechOpen, London, UK. Available at: https://tinyurl. com/w7umck3.
Spellman, D., McEvoy, E., O'Cuinn, G. and FitzGerald, F.J., 2003. Proteinase and exopeptidase hydrolysis of whey protein: comparison of the TNBS, OPA and PH stat methods for quantification of degree of hydrolysis. International Dairy Journal 13: 447-453. https://doi. org/10.1016/S0958-6946(03)00053-0

Tuck, C., Pérez, E., Horváth, I., Sheldon, R. and Poliakoff, M., 2012. Valorization of biomass: deriving more value from waste. Science 337: 695-699. https://doi.org/10.1126/science.1218930

Van Huis, A., 2013. Potential of insects as food and feed in assuring food security. Annual Review of Entomology 58: 563-583. https:// doi.org/10.1146/annurev-ento-120811-153704

Yi, L., Van Boekel, M.A.J.S. and Lakemond, C.M.M., 2017. Extracting Tenebrio molitor protein while preventing browning: effect of $\mathrm{pH}$ and $\mathrm{NaCl}$ on protein yield. Journal of Insects as Food and Feed 3: 21-31. https://doi.org/10.3920/JIFF2016.0015

Zhao, Q., Xiong, H., Selomulya, C., Chen, X.D., Zhong, H., Wang, S. and Zhou, Q., 2012. Enzymatic hydrolysis of rice dreg protein: effects of enzyme type on the functional properties and antioxidant activities of recovered proteins. Food Chemistry 134: 1360-1367. https://doi.org/10.1016/j.foodchem.2012.03.033

Zhao, X., Vázquez-Gutiérrez, J.L., Johansson, D.P., Landberg, R. and Langton, M., 2016. Yellow mealworm protein for food purposes - extraction and functional properties. PLoS ONE 11: e0147791. https://doi.org/10.1371/journal.pone.0147791. 